\title{
Production, characterization and optimization of fermented tomato and carrot juices by using Lysinibacillus sphaericus isolate
}

\author{
Naga Sivudu Seelam, Harika Akula, Umamahesh Katike, Vijaya Sarathi Reddy Obulam* \\ Department of Biochemistry, Sri Venkateswara University, Tirupati - 517 502, Andhra Pradesh, India.
}

\begin{tabular}{|c|c|}
\hline ARTICLE INFO & ABSTRACT \\
\hline $\begin{array}{l}\text { Article history: } \\
\text { Received on: } 03 / 03 / 2017 \\
\text { Accepted on: } 11 / 06 / 2017 \\
\text { Available online: } 14 / 08 / 2017\end{array}$ & $\begin{array}{l}\text { Fermentation of tomato and carrot juices was carried out with a native isolate of Lysinibacillus sphaericus. } \\
\text { Initial screening showed that total phenolics, antioxidants and titratable acidity were higher in both the } \\
\text { fermented juices than respective un-fermented controls. Better fermentation characteristics were found in } \\
\text { fermented tomato juice at } 37^{\circ} \mathrm{C}\left(\mathrm{pH} 5.8 \text {, TA\% } 0.38 \text { and cell viability of } 7.8 \times 10^{7} \mathrm{CFU} / \mathrm{mL}\right) \text { than those of }\end{array}$ \\
\hline $\begin{array}{l}\text { Key words: } \\
\text { Tomato and Carrot juices, } \\
\text { Lysinibacillus sphaericus, } \\
\text { Fermentation, Response surface } \\
\text { methodology, Antimicrobial } \\
\text { activity. }\end{array}$ & $\begin{array}{l}\left.\text { fermented carrot juice (pH 5.5, TA\% } 0.30 \text { and cell viability of } 6.9 \times 10^{7} \mathrm{CFU} / \mathrm{mL}\right) \text {. Hence, fermentation of } \\
\text { tomato juice was optimized by Central Composite Design using temperature, } \mathrm{pH} \text {, incubation time and sucrose } \\
\text { concentrations as critical parameters. The optimized conditions for fermentation of tomato juice were } \\
\text { determined to be pH } 6.2 \text {, temperature of } 37^{\circ} \mathrm{C} \text {, inoculum size of } 7.58 \mathrm{log} \mathrm{CFU} / \mathrm{mL} \text {, sucrose concentration of } \\
10 \% \text { and fermentation for } 24 \mathrm{~h} \text {. The antimicrobial activity of the fermented tomato juice against Bacillus } \\
\text { cereus MTCC } 7190 \text { was better (inhibition zone of } 10 \mathrm{~mm} \text { ) than the fermented carrot juice }(8 \mathrm{~mm}) \text {. The cell } \\
\text { viability of L. sphericus at } 4^{\circ} \mathrm{C} \text { for } 6 \text { weeks was better in tomato juice }\left(0.9 \times 10^{6}\right) \text { than in the carrot juice }(0.6 \\
\left.\text { x } 10^{6} \mathrm{CFU} / \mathrm{mL}\right) \text {. Fermented juices exhibited good sensory attributes and could possibly be used as probiotic } \\
\text { drinks. }\end{array}$ \\
\hline
\end{tabular}

\section{INTRODUCTION}

The interest in probiotic products has been increasing during the last two decades due to the health awareness of consumers [1]. Probiotics are defined as "live microorganisms which when administered in adequate amounts confer a health benefit on the host" [2]. Present industrial probiotic foods are mainly dairy products, which may represent inconveniences due to their lactose and cholesterol content [3]. However, there is a real interest in the development of fruit juice based functional beverages with probiotics, because they have taste profiles that are appealing to all age groups and also they act as healthy and refreshing foods $[4,5]$. Probiotic microorganisms are reported to have many health-supporting effects. They are useful in prevention of infections in intestine, colon cancer and avoid constipation. Probiotcs have good characteristics like resistance to acid, bile, attachment to epithelial cells and colonization in the stomach [6]. Vegetable juices are also considered as ideal media for cultivating probiotic microorganisms, because they do not contain any dairy allergens that might prevent usage by certain

* Corresponding Author

Vijaya Sarathi Reddy Obulam, Department of Biochemistry,

Sri Venkateswara University, Tirupati - 517 502, India.

Email: ovsreddy@yahoo.com kind of the population [7]. Regular consumption of tomatoes has been associated with a reduced risk of various types of cancer [8] and heart deseases [9]. Positive effects are mainly attributed to the presence of antioxidants, especially carotenoids, flavonoids, lycopene and beta-carotene. Carrot juice contains (for $100 \mathrm{~g}$ ): carbohydrates $9.6 \mathrm{~g}$, sugars $4.7 \mathrm{~g}$, dietary fiber $2.8 \mathrm{~g}$, protein 0.93 $\mathrm{g}$, fat $0.24 \mathrm{~g}$, vitamin A, C, B1, B2, B3, B6 and E. Carrot is rich source of carotenes, antioxidants and polyacetylenes (especially falcarinol), have the ability to inhibit growth of colon cancer cells [10]. In the present study tomatoes and carrots are used for the production of fermented juices. Response surface methodology (RSM) is a useful statistical technique which has been applied in the research involved in complex variable processes. It uses multiple regression and correlation analyses as tools to assess the effects of two or more independent factors on the dependent variables. Its principal advantage is the reduced number of experimental runs required to generate sufficient information for a statistically acceptable result [11]. It is also an efficient tool for the evaluation of the simultaneous effect of some important technological and microbiological parameters on the acidification rate and the growth of starter bacteria during the fermentation process of yoghurt and it has been successfully used to determine and optimize the rheological properties and gelation kinetics of yoghurt [12]. 
Lysinibacillus is commonly found in soil, plants and animals. The genome of Lysinibacillus sphaericus was the first strain in the genus Lysinibacillus which is taxonomically classified on the basis of cell wall and peptidoglycan. The antimicrobial potential of Lysinibacillus has been reported and its bacteriocin used as food preservative to combat against food-borne bacterial and fungal pathogens [13].

The main aim of the present study was to characterize the Lys. sphaericus isolate and to optimize its growth in tomato and carrot juices. Other aims include phyto-chemical analyses of the fermented juices and their antagonistic activity as well as determining the shelf-life of the viability of Lys. sphaericus isolate in tomato and carrot juices during storage at $4^{\circ} \mathrm{C}$.

\section{MATERIALS AND METHODS}

\subsection{Source of Microorganism}

Lysinibacillus sphaericus isolate [14] was collected from Microbial Biochemistry Laboratory, Department of Biochemistry, Sri Venkateswara University, Tirupati.

\subsection{Biochemical characterization}

To determine the ability of the isolate to grow in $\mathrm{NaCl}$, MRS tubes containing 2, 4, 6, 8 and $12 \% \mathrm{NaCl}$ were inoculated with a loopful of actively growing $24 \mathrm{~h}$ old culture of Lys. sphaericus and incubated at $37{ }^{\circ} \mathrm{C}$ for $72 \mathrm{~h}$. To determine the optimum growth temperature, the culture was inoculated in $10 \mathrm{~mL}$ of sterile MRS broth tubes and was incubated at 20, 25, 30, 35, 37, 40 and $45^{\circ} \mathrm{C}$ for $24-48 \mathrm{~h}$. To optimize the $\mathrm{pH}$ for growth, the $\mathrm{pH}$ of the MRS broth was adjusted from 9.2 to 9.8 , individually, and a loopful of $24 \mathrm{~h}$ old culture was added to each tube and incubated at $37^{\circ} \mathrm{C}$ for $72 \mathrm{~h}$.

\subsection{Acid and bile tolerance test}

Resistance to $\mathrm{pH} 3$ is often used in vitro assay to determine the possible resistance to stomach $\mathrm{pH}$. Because the foods stay in the stomach for $3 \mathrm{~h}$, this period of time limit was taken into account [15]. For this purpose, actively growing culture $(18 \mathrm{~h})$ was used. Cells were harvested by centrifugation for $10 \mathrm{~min}$ at $8000 \mathrm{rpm}$ and $4^{\circ} \mathrm{C}$.

The cell pellets were washed once in phosphate buffer saline (PBS at $\mathrm{pH}$ 7.2) and were resuspended in PBS (pH 3) and incubated at $37{ }^{\circ} \mathrm{C}$. Viable microorganisms were enumerated after the incubation for $0,1,2$ and $3 \mathrm{~h}$ by following pour plate technique.

The plates were incubated at $37^{\circ} \mathrm{C}$ under anaerobic conditions for $48 \mathrm{~h}$ and the viable counts were enumerated. Bile salt tolerance is potentially a probiotic property of LAB cultures. In this experiment, MRS broth containing $0.3 \%$ of bile salt (taurocholic acid) was inoculated with Lys. sphaericus and incubated at $37^{\circ} \mathrm{C}$ for $24 \mathrm{~h}$. The control comprised of MRS broth without bile salt. Bacterial growth was monitored by measuring optical density at $600 \mathrm{~nm}$ after overnight incubation.

\subsection{Preparation of vegetable juices}

Fresh carrots (Daucus carota $\mathrm{L}$ ) and tomatoes (Solanam lycopersicum $\mathrm{L}$ ) were purchased from a local vegetable market in Tirupati, India and were stored in a box at room temperature for further maturation (5 - 7 days). The matured vegetables were washed with tap water to remove soil and other impurities, airdried at room temperature and treated with steam for 3 to $4 \mathrm{~min}$ for easy peeling. Juice was prepared from homogenized skinless slices of tomatoes and carrots, separately, by using a laboratory grinder and filtered through a muslin cloth to get a clear juice.

\subsection{Inoculum preparation}

The isolated culture was maintained in MRS agar stabs as pure cultures. It was grown in two successive MRS broth cultures at $37{ }^{\circ} \mathrm{C}$ for $24 \mathrm{~h}$. The activated culture was again inoculated into MRS broth incubated at $37^{\circ} \mathrm{C}$ for $24 \mathrm{~h}$ and this was used as the inoculum.

\subsection{Fermentation of tomato and carrot juices}

The tomato and carrot juices $(100 \mathrm{~mL})$ were taken in 250 $\mathrm{mL}$ Erlenmeyer flasks, individually and autoclaved for $15 \mathrm{~min}$ at $121^{\circ} \mathrm{C}$. The flasks were inoculated with actively growing cells of Lys. sphaericus $\left(10^{9} \mathrm{CFU} / \mathrm{mL}\right)$ and incubated at $37{ }^{\circ} \mathrm{C}$ for $72 \mathrm{~h}$.

\subsection{Optimization using central composite design (CCD)}

Fermentation process was optimized using response surface methodology (RSM) protocol [16]. The effect of $\mathrm{pH}\left(\mathrm{X}_{1}\right)$, temperature $\left(\mathrm{X}_{2}\right)$, time $\left(\mathrm{X}_{3}\right)$ and sucrose $\left(\mathrm{X}_{4}\right)$ on cell viability $\left(\mathrm{Y}_{1}\right)$, biomass $\left(\mathrm{Y}_{2}\right)$, and acidity $\left(\mathrm{Y}_{3}\right)$ of Lys. sphaericus in vegetable juices was studied through central composite design according to response surface methodology using Design-Expert version 9 (Stat-Ease Inc., Minneapolis, MN, USA) software. The range and the levels of the variables investigated in this CCD study are given in the Table 4. A $2^{4}$-factorial CCD, with six replications at the centre points $\left(\mathrm{n}_{0}=6\right)$ leading to a total number of 30 experiments were employed (Table 5 and 6) for the optimization of the fermentation conditions. The second degree polynomials equations were used with the statistical package to approximate the response of the dependent process variable. Variance determined for each factor was divided into linear, quadratic and interactive components and were represented using the second order polynomial function as follows.

$\mathrm{Y}=\mathrm{b}_{0}+\mathrm{b}_{1} \mathrm{X}_{1}+\mathrm{b}_{2} \mathrm{X}_{2}+\mathrm{b}_{3} \mathrm{X}_{3}+\mathrm{b}_{4} \mathrm{X}_{4}+\mathrm{b}_{11} \mathrm{X}_{1}^{2}+\mathrm{b}_{22} \mathrm{X}_{2}^{2}+\mathrm{b}_{33} \mathrm{X}_{3}^{2}+$ $b_{44} X_{4}^{2}+b_{12} X_{1} X_{2}+b_{13} X_{1} X_{3}+b_{14} X_{1} X_{4}+b_{23} X_{2} X_{3}+b_{24} X_{2} X_{4}+$ $b_{34} X_{3} X_{4}$

Where $\mathrm{Y}$ is the predicted response, $\mathrm{X}_{1}, \mathrm{X}_{2}, \mathrm{X}_{3}$ and $\mathrm{X}_{4}$ were independent variables, $b_{0}$ is the offset term, $b_{1}, b_{2}, b_{3}$ and $b_{4}$ were linear effects, $b_{11}, b_{22}, b_{33}$ and $b_{44}$ were squared effects and $b_{12}, b_{13}, b_{14}, b_{23}, b_{24}$ and $b_{34}$ were interaction terms. The significance of all terms in the polynomial functions were assessed statistically using F-value at a probability (P) of $0.001,0.01$ or 0.05 . The threedimensional (3D) plots were generated by keeping one variable constant at the centre point and varying the other variables within the experimental range. Optimized values of four independent 
variables for maximum activities were determined using a numerical optimization package of Design-Expert version 9.

\subsection{Chemical characterization}

The $\mathrm{pH}$ of fermented carrot and tomato juice was measured with a $\mathrm{pH}$ meter. Total acidity (TA), is expressed as percent oxalic acid, and was determined by titrating the vegetable juice samples with $0.1 \mathrm{~N} \mathrm{NaOH}$ to $\mathrm{pH} 8.2$, using phenolphthalein indicator. Total soluble solids (TSS) are determined using a hand Refractometer (0-30) (Erma, Japan) in terms of ${ }^{\circ} \mathrm{Bx}\left({ }^{\circ} \mathrm{Brix}\right)$.

\subsection{Biomass and cell viability determination}

The cell concentration was determined by measuring the optical density of the cell suspension. Samples of the fermented juice were adequately diluted in water and the absorbance was read at $590 \mathrm{~nm}$. The number of viable cells was determined as CFU. Serial decimal dilutions of each sample were plated in triplicate onto MRS agar and incubated at $37^{\circ} \mathrm{C}$ for $72 \mathrm{~h}$. The colonies as viable count was determined and the results were expressed as $\log \mathrm{CFU} / \mathrm{mL}$.

\subsection{Antimicrobial activity of fermented juices}

The agar-well-diffusion method was used to determine the antimicrobial property of the fermented vegetable juices. A 24 h culture of the pathogenic strains (Escherichia coli MTCC 40, Bacillus cereus MTCC 6840, B. cereus MTCC 7190) were grown individually in Luria Broth (LB) medium and the cell suspension was spread over the surface of Muller-Hilton agar plates using sterile spreaders. The plates were allowed to dry and a sterile well borer of $5 \mathrm{~mm}$ diameter was used to cut uniform wells in the agar. Each well was filled with $100 \mu \mathrm{L}$ of cell-free fermented juice of tomato or carrot. After incubation at $37^{\circ} \mathrm{C}$ for $24 \mathrm{~h}$, the plates were observed for a zone of inhibition (ZOI) around the well. Results were considered positive if the diameter of the ZOI was greater than $1 \mathrm{~mm}$ [17].

\subsection{Sample preparation and sugar extraction}

Vegetable juices were treated individually with heatstable $\alpha$-amylase, protease, and amylo glucosidase in order to hydrolyze starch and proteins. HPLC analysis of carbohydrates was carried out by the procedure described earlier [18]. The chromatographic system consisted of a Shimadzu Chromatograph (Model LC6A) equipped with the system controller, SCL6A, RID10A RI detector, an integrator C-R3A chromate pack and stainless steel LC-NH2 $25 \mathrm{~cm} \mathrm{X} 4.6 \mathrm{~mm}$ column preceded by a Supel-guard column containing LC-NH ${ }_{2}$ packing (Supelcosil, $5 \mu \mathrm{m}$ particle size). The sample extract $(10 \mu \mathrm{L})$ was injected into the HPLC column. Isocratic separation of carbohydrate fractions was accomplished, with a mobile phase consisting of acetonitrile: water $(80: 20 \mathrm{v} / \mathrm{v})$ at a flow rate of $1 \mathrm{~mL}$ per min. The HPLC was calibrated by injecting $10 \mu \mathrm{L}$ of a mixture of standard sugars (fructose, glucose, sucrose, maltose and lactose, all from Fluca Chemicals, USA) and the concentration of each sugar ranging from 4.5 to $9.6 \mathrm{mg} / \mathrm{mL}$. The sugars present in the vegetable juices were identified by referring to standards.

\subsection{Estimation of total phenolic content (TPC)}

The TPC was determined by using Folin-Ciocalteu method as described by Singleston and Rossi [19]. Briefly, 0.5 $\mathrm{mL}$ of appropriately diluted juice samples or standard solutions of gallic acid was pipetted in to test tube, along with $5 \mathrm{~mL}$ of distilled water, $0.5 \mathrm{~mL}$ of Folin-Ciocalteu reagent, and the mixture was allowed to react for $3 \mathrm{~min}$. For color development $1 \mathrm{~mL}$ of $20 \%$ $\mathrm{Na}_{2} \mathrm{CO}_{3}$ solution was added, mixed well and then left to stand for 1 $\mathrm{h}$ at $37^{\circ} \mathrm{C}$. Absorbance against prepared reagent blank was measured at $750 \mathrm{~nm}$ using a Spectrophotometer and the TPC content was expressed in $\mathrm{mg}$ GAE/100 mL.

\subsection{DPPH (1,1-diphenyl, 2-picrylhydrazyl) radical scavenging activity}

A stock solution was prepared by dissolving $14 \mathrm{mg}$ of DPPH in $100 \mathrm{~mL}$ methanol and then stored at $-20^{\circ} \mathrm{C}$ [20]. The working solution was obtained by mixing $10 \mathrm{~mL}$ stock solution with $45 \mathrm{~mL}$ methanol to obtain an absorbance of $1.1 \pm 0.02$ units at $517 \mathrm{~nm}$ using a Spectrophotometer. Different volumes of various vegetable juices $(50-200 \mu \mathrm{L})$ were allowed to react with DPPH solution (final volume $4 \mathrm{~mL}$ ) and were shaken vigorously and allowed to stand for $30 \mathrm{~min}$ in dark at room temperature. Methanol was used as a blank. BHT (butylated hydroxyl toluene) was used as a standard [21]. A control sample with no added vegetable juice was also analyzed and radical-scavenging activity (\% inhibition) was calculated using the following equation. DPPH free radical scavenging activity $(\%)=[(\mathrm{A}$ control $-\mathrm{A}$ sample $) / \mathrm{A}$ control $] \times$ $100(\mathrm{~A}=$ absorbance at $517 \mathrm{~nm})$.

\subsection{Effect of cold storage on cell viability in fermented tomato and carrot juice}

After $72 \mathrm{~h}$ of fermentation, the samples of tomato and carrot juice were subjected for storage studies in order to evaluate cell viability [22]. Fermented juice samples $(200 \mathrm{~mL})$ were dispensed aseptically into $250 \mathrm{~mL}$ amber sterile glass bottles. The bottles were closed with screw caps and stored at $4^{\circ} \mathrm{C}$ for 6 weeks. Biomass, $\mathrm{pH}$ and viable cell counts were expressed as colony forming units per $\mathrm{mL}(\mathrm{CFU} / \mathrm{mL})$ were determined and recorded prior to cold storage, and at weekly intervals for 6 weeks during storage.

\subsection{Sensory evaluation}

The sensory characteristics of the vegetable juices were evaluated according to Dias et al. [23] with a 20-membered panel. The preferences for taste, acidity, mouth feel, aroma, flavour, color and overall acceptability were determined by 9-point Hedonic scale. Randomized refrigerated $\left(10^{\circ} \mathrm{C}\right)$ samples $(50 \mathrm{~mL})$ were served in clear tulip- shaped glasses coded with a random 3-digit code. The mean intensity scores of all the attributes were calculated and plotted. 


\subsection{Statistical analysis}

All the experiments were carried out in triplicate and the mean value and standard deviation were presented. The data were analyzed by one-way analysis of variance (ANOVA) using SPSS, version 16.0.

\section{RESULTS AND DISCUSSION}

\subsection{Isolation and characterization of the strain}

In the present study the Lys. spharecius was used for fermentation of tomato and carrot juices in order to characterize its potential as probiotic bacterium. The isolated Lys. spharecius was rod-shaped, Gram-positive, catalase negative and produced ammonia from arginine hydrolysis, which is the main characteristic feature, as observed with all Lactobacilli, and the results are presented in Table 1.

Table 1: Characteristic features of Lys. sphaericus isolate.

\begin{tabular}{cc}
\hline Parameter & Observation \\
\hline Cell morphology & Rod shaped \\
Grams staining & + \\
Growth at temperature $10-45^{\circ} \mathrm{C}$ & + \\
Growth at pH range pH $3.0-9.6$ & + \\
Growth at NaCl concentration $1-10 \%$ & + \\
Catalase & - \\
Arginine hydrolysis & + \\
Fermentation of carbohydrates & + \\
Acid tolerance & + \\
Bile salt tolerance & + \\
\hline
\end{tabular}

The culture could grow at different temperatures (20 to $45^{\circ} \mathrm{C}$ ), $\mathrm{pH}$ (2.0 to 9.8 ) and $\mathrm{NaCl}$ concentrations ( 2 to $12 \%$ ) and in the presence of bile salt. It was found to be resistant at a low $\mathrm{pH}$ for $4 \mathrm{~h}$. It showed better survival after treatment of cells in the presence of pepsin ( $\mathrm{pH} 2.0)$ for $1 \mathrm{~h}$, and the viability decreased significantly beyond $3 \mathrm{~h}$. The survival of the strain at $\mathrm{pH} 6.4-6.7$ was also tested using $0.3 \%$ taurocholic acid. The results showed that $10^{5} \mathrm{CFU} / \mathrm{mL}$ survived even after $14 \mathrm{~h}$ at $37^{\circ} \mathrm{C}$, and then significantly decreased up to $24 \mathrm{~h}$. A 1 and $2 \%$ bile salt hydrolase (BSH) activity for $3 \mathrm{~h}$ with a viable count of $10^{4}-10^{3} \mathrm{CFU} / \mathrm{mL}$ were reported earlier [15]. The above results support that the strain is tolerant to both environments, i.e., acidic conditions $(\mathrm{pH} 2.0$ 3.0 ) and in the presence of bile (Table 1).

\subsection{Fermentation of tomato and carrot juices}

Two vegetable juices prepared using tomatoes and carrots independently were selected for fermentation, and tomato juice was found to have higher viable count of $7.8 \log \mathrm{CFU} / \mathrm{mL}$ with a final $\mathrm{pH}$ of 5.8 and TA\% (0.38) than carrot juice which had a viable count of $6.9 \log \mathrm{CFU} / \mathrm{mL}$ with a final $\mathrm{pH}$ of 5.5 and TA\% (0.30) (Table 2). Hence, tomato was selected for further fermentation and for optimization of the product preparation. These results are similar to an earlier report on the use of vegetable and fruit juices for fermentation by four lactic acid bacteria ( $L b$. acidiphillus LA39, Lb. plantarum C3, Lb. casei A4 and Lb. delbrueckii D7) [3] and tomato juice has been well recognized as one of the healthy beverages [24].

Physico-chemical properties like TSS, pH, TA, and cell viability of fermented tomato and carrot juices are presented in Table 2. Total soluble solids (TSS) were still higher in tomato juice than that of carrot juice at $24 \mathrm{~h}$. of fermentation. However, titratable acidity and cell viability were increased in up to $24 \mathrm{~h}$ and later decreased, whereas, the $\mathrm{pH}$ gradually decreased from 6.8 to 4.1 during fermentation of $72 \mathrm{~h}$. An increase in TA\% from 0.12 to 0.38 was noticed within $24 \mathrm{~h}$. Fermentation improved the utilization of sugars as indicated by decrease in their contents as the fermentation time increased from 24 to $72 \mathrm{~h}$ (Table 2). These results corroborate with the probiotication of mixed water melon and tomato juice [25].

Sugars levels were gradually decreased during fermentation period of $72 \mathrm{~h}$ in tomato and carrot juices as compared to control juices (Figure 1). The biomass and cell viability increased gradually during first $24 \mathrm{~h}$ fermentation by rapidly consuming the substrates (sugars) present in the tomato and carrot juices and liberated their products into the medium. Later slowly decreased due to, depletion of nutrients and reduction in $\mathrm{pH}$ (Figure 2). These results corroborate with the probiotication of tomato juice by Yoon et al. [26].

The DPPH radical scavenging activity gradually increased in fermented tomato and carrot juices as the fermentation period increased, and it was less in unfermented juices (Figure 3). Fermented tomato and carrot juices showed more antioxidant activity than control juices. This observation is in agreement with an earlier report [27]. The total TPC content increased significantly in both fermented tomato and carrot juices during 72 $\mathrm{h}$ of fermentation (Figure 4). When compared to unfermented juices $(310 \mathrm{mg} / \mathrm{GAE} / 100 \mathrm{~mL}$ ), fermented tomato and carrot juices had higher levels of TPC (392 mg/GAE/100 mL). In tomato juice, TPC enhanced gradually with increase in fermentation period, and these results are in agreement with an earlier report on probiotication of mango and sapota juices using $\mathrm{Lb}$. plantarum [21].

The antimicrobial activity of the both fermented tomato and carrot juices was evaluated against $E$. coli MTCC 40, B. cereus MTCC 6840 and B. cereus MTCC7190 as compared to the Ampicillin control and their inhibition zone sizes are presented in (Table 3). Fermented tomato juice efficiently inhibited the growth of $B$. cereus followed by $E$. coli, with a maximum zone of inhibition of 10 and $9.1 \mathrm{~mm}$, respectively, whereas, fermented carrot juice showed an inhibition zone of 8.5 and $8.2 \mathrm{~mm}$ against $B$. cereus and $E$. coli, respectively.

The fermented tomato and carrot juices were stored in refrigerator for six weeks at $4^{\circ} \mathrm{C}$ in order to study the shelf-life of the cell viability. Viability of Lys. sphaericus in the juices during the storage period was analyzed weekly and the results are presented in Table 4. The cell count was reduced to below initial level $(2.5 \log \mathrm{CFU} / \mathrm{mL})$ in tomato and carrot juices after six weeks of storage at $4{ }^{\circ} \mathrm{C}$. 
Table 2: Physico-chemical analyses of tomato and carrot juices fermented with Lys. Sphaericus.

\begin{tabular}{|c|c|c|c|c|c|}
\hline Type of juice & Time (h) & $\begin{array}{c}\text { TSS } \\
\text { (Brix) }\end{array}$ & Titratable acidity (\%) & pH & $\begin{array}{l}\text { Cell viability } \\
\text { (CFU/ mL) }\end{array}$ \\
\hline \multirow{4}{*}{ FTJ } & 12 & $19 \pm 0.8$ & $0.28 \pm 0.08$ & $6.6 \pm 0.04$ & $6.5 \pm 0.6 \times 10$ \\
\hline & 24 & $17 \pm 1.0$ & $0.38 \pm 0.03$ & $5.8 \pm 0.04$ & $7.8 \pm 0.9 \times 10^{7}$ \\
\hline & 48 & $13 \pm 0.8$ & $0.31 \pm 0.02$ & $4.7 \pm 0.08$ & $7.1 \pm 0.5 \times 10^{6}$ \\
\hline & 72 & $10 \pm 0.8$ & $0.21 \pm 0.08$ & $4.1 \pm 0.08$ & $5.5 \pm 0.3 \times 10^{6}$ \\
\hline \multirow{4}{*}{ FCJ } & 12 & $18 \pm 0.47$ & $0.22 \pm 0.016$ & $6.5 \pm 0.04$ & $6.2 \pm 0.6 \times 10^{8}$ \\
\hline & 24 & $16 \pm 0.81$ & $0.36 \pm 0.08$ & $5.5 \pm 0.04$ & $6.9 \pm 0.9 \times 10^{7}$ \\
\hline & 48 & $14 \pm 0.47$ & $0.30 \pm 0.004$ & $4.3 \pm 0.04$ & $6.6 \pm 0.5 \times 10^{6}$ \\
\hline & 72 & $11 \pm 0.81$ & $0.20 \pm 0.08$ & $3.8 \pm 0.04$ & $6.0 \pm 0.3 \times 10^{6}$ \\
\hline
\end{tabular}

FTJ (Fermented tomato juice), FCJ (Fermented carrot juice).

Table 3: Antimicrobial activity of fermented tomato and carrot juice.

\begin{tabular}{cccc}
\hline Sample & \multicolumn{3}{c}{ Zone of inhibition (mm) } \\
\hline & E. coli MTCC 40 & B. cereus MTCC 6840 & B. cereus MTCC 7190 \\
\hline FTJ (A) & $9.1 \pm 0.1$ & $8.2 \pm 0.2$ & $10 \pm 0.1$ \\
FCJ (B) & $8.2 \pm 0.2$ & $7.8 \pm 0.1$ & $8.5 \pm 0.3$ \\
Ampicillin (C) & $13.77+1.74$ & $16.23+0.86$ & $18.73+0.27$ \\
\hline
\end{tabular}

Table 4: Viability of Lys. sphaericus stored at $4^{\circ} \mathrm{C}$ over a period of 6 weeks.

\begin{tabular}{|c|c|c|c|}
\hline \multirow{2}{*}{ Storage (weeks) } & \multicolumn{3}{|c|}{ Cell viability of Lys. sphaericus at $4^{\circ} \mathrm{C}(\mathrm{CFU} / \mathrm{mL})$} \\
\hline & FTJ & FCJ & FTJ + FCJ \\
\hline 0 & $4.5 \pm 0.6 \times 10^{8}$ & $4.2 \pm 0.4 \times 10$ & $4.0 \pm 0.8 \times 10^{8}$ \\
\hline 1 & $4.0 \pm 0.9 \times 10^{7}$ & $3.9 \pm 0.2 \times 10^{6}$ & $3.7 \pm 0.6 \times 10^{6}$ \\
\hline 2 & $3.8 \pm 0.5 \times 10^{6}$ & $3.4 \pm 3.4 \times 10^{6}$ & $3.2 \pm 0.7 \times 10^{6}$ \\
\hline 3 & $3.2 \pm 0.3 \times 10^{6}$ & $3.0 \pm 3.4 \times 10^{6}$ & $2.8 \pm 0.3 \times 10^{6}$ \\
\hline 4 & $2.5 \pm 0.4 \times 10^{6}$ & $2.2 \pm 0.3 \times 10^{6}$ & $1.9 \pm 0.6 \times 10$ \\
\hline 5 & $1.7 \pm 0.2 \times 10^{6}$ & $1.4 \pm 0.3 \times 10^{6}$ & $1.1 \pm 0.6 \times 10$ \\
\hline 6 & $0.9 \pm 0.2 \times 10^{6}$ & $0.6 \pm 0.2 \times 10^{6}$ & $0.3 \pm 0.2 \times 10^{6}$ \\
\hline
\end{tabular}

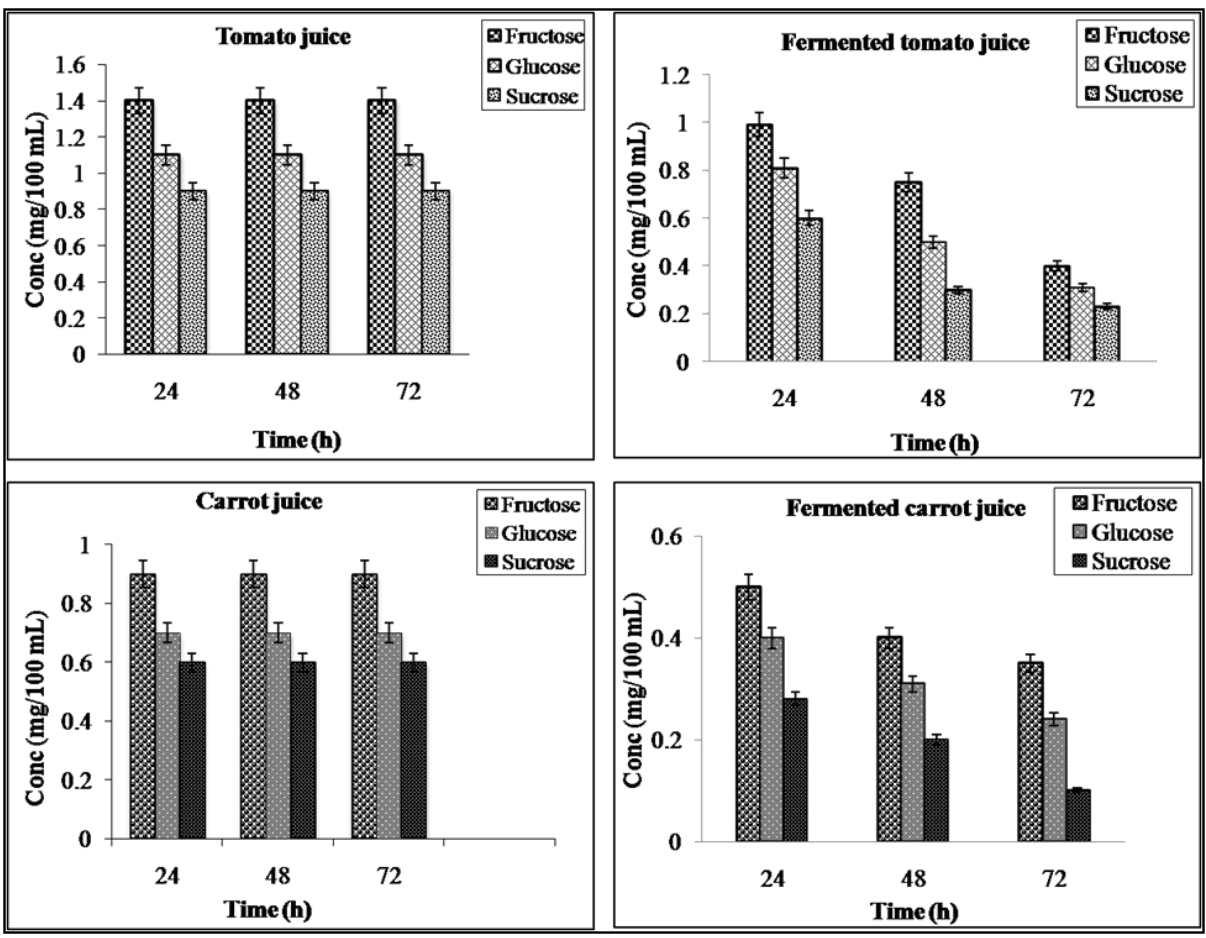

Fig. 1: HPLC sugar profile of control and fermented tomato and carrot juices. 


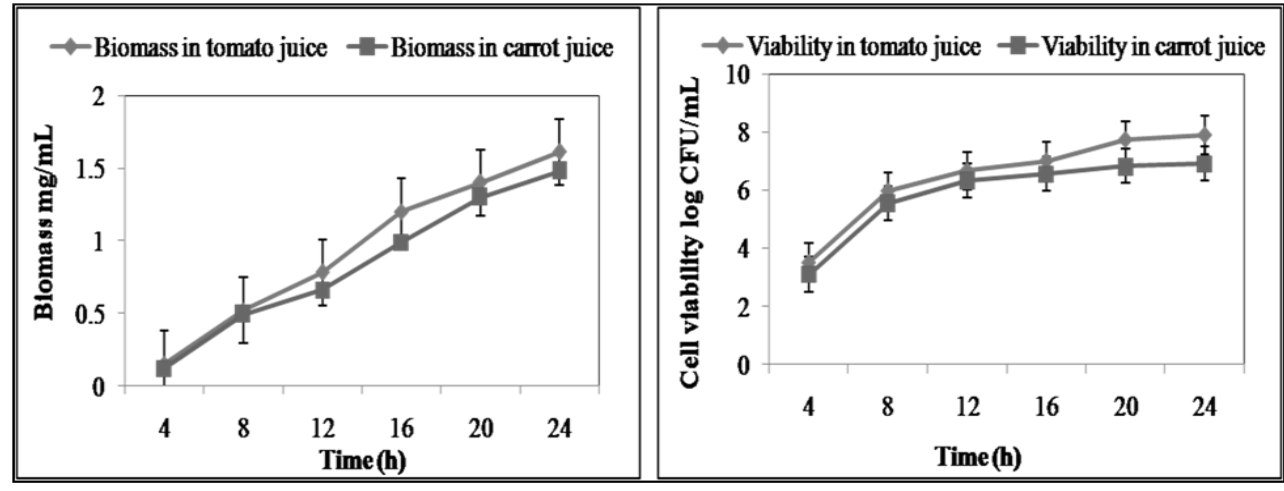

Fig. 2: Cell viability and biomass in fermented tomato and carrot juices.

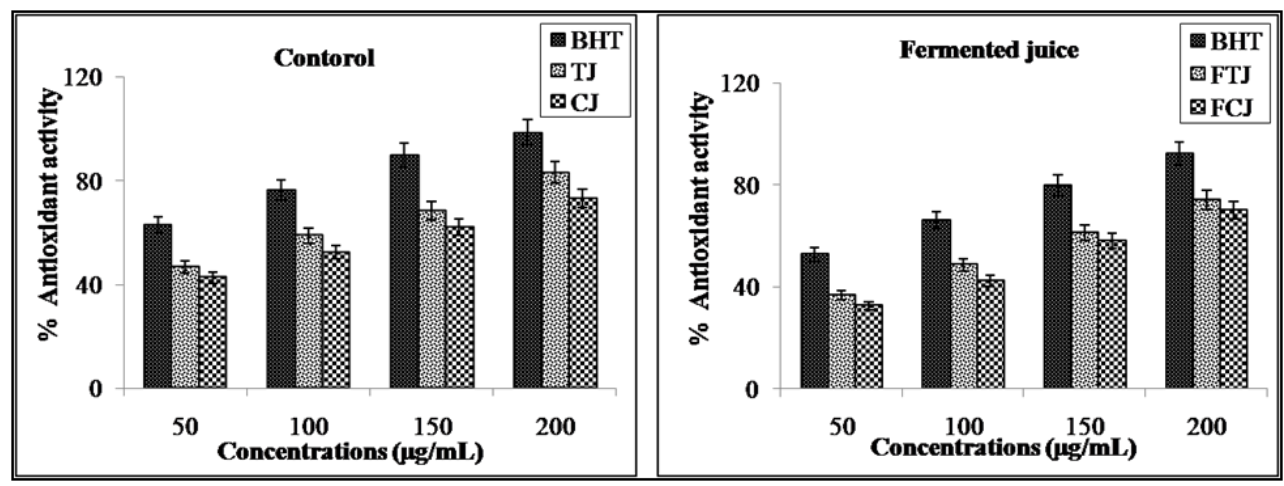

Fig. 3: DPPH scavenging activity of fermented juices.

(BHT- Butylated hydroxyl toluene, FTJ - Fermented tomato juice, FCJ - Fermented carrot juice).

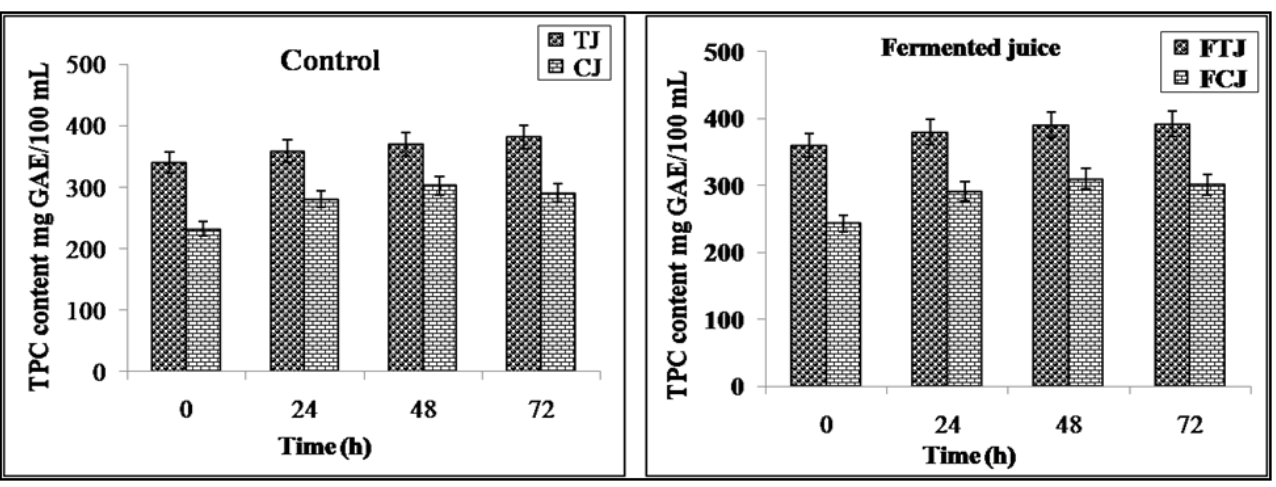

Fig. 4: Total phenolic content in control and fermented tomato and carrot juices.

\subsection{Optimization of tomato juice production using RSM}

Optimization of process conditions is one of the most critical stages in the development of an efficient and economic bioprocess [28]. The influence of $\mathrm{pH}$, temperature, time and sucrose on acidity, cell viability, and biomass was investigated using RSM. For each run, the experimental responses along with predicted responses were calculated from the regression equation (Eq. 2, 3, 4) and the actual and predicted values of variables were presented in Table 5. The effect of each factor and its interaction was analyzed using the analysis of variance (ANOVA) and $\mathrm{X}^{2}$ test as appropriate to the experimental design used. Calculated regression equation for the optimization of fermentation conditions showed that the cell viability (Y1, CFU/mL), biomass (Y2, O.D) and acidity $(\mathrm{Y} 3, \%)$ are functions of the $\mathrm{pH}\left(\mathrm{X}_{1}\right)$, temperature $\left(\mathrm{X}_{2}\right.$, $\left.{ }^{\circ} \mathrm{C}\right)$, time $\left(\mathrm{X}_{3}, \mathrm{~min}\right)$ and sucrose $\left(\mathrm{X}_{4}, \%\right)$. By applying multiple regression analysis on the experimental model data, the following second order polynomial equation is found to represent the cell viability, biomass and acidity effectively.

Cell viability (CFU) $\mathrm{Y}_{1}=30.1+4.7 \mathrm{X}_{1}+1.0 \mathrm{X}_{2}+0.08 \mathrm{X}_{3}+1.5 . \mathrm{X}_{4}$ $0.51 \mathrm{X}_{1}^{2}-0.01 \mathrm{X}_{2}^{2}-4.16 \mathrm{X}_{3}^{2}-0.09 \mathrm{X}_{4}^{2}+5.63 \mathrm{X}_{1} \mathrm{X}_{2}+1.59 \mathrm{X}_{1} \mathrm{X}_{3}+0.03$ $\mathrm{X}_{1} \mathrm{X}_{4}-8.39 \mathrm{X}_{2} \mathrm{X}_{3}+3.0 \mathrm{X}_{2} \mathrm{X}_{4}+6.55 \mathrm{X}_{3} \mathrm{X}_{4}$

Biomass (O.D) $\mathrm{Y} 2=3.18+0.46 \mathrm{X}_{1}+0.10 \mathrm{X}_{2}+7.42 \mathrm{X}_{3}+0.18 . \mathrm{X}_{4}-0.05 \mathrm{X}_{1}^{2}$ $1.43 \mathrm{X}_{2}^{2}-5.92 \mathrm{X}_{3}^{2}-9.83 \mathrm{X}_{4}^{2}+3.37 \mathrm{X}_{1} \mathrm{X}_{2}+5.06 \mathrm{X}_{1} \mathrm{X}_{3}+2.25 \mathrm{X}_{1} \mathrm{X}_{4}-6.94 \mathrm{X}_{2} \mathrm{X}_{3}$ $+1.85 \mathrm{X}_{2} \mathrm{X}_{4}+4.62 \mathrm{X}_{3} \mathrm{X}_{4}$ 
Acidity $(\%) \mathrm{Y} 3=8.76+0.16 \mathrm{X}_{1}+0.07 \mathrm{X}_{2}+4.72 \mathrm{X}_{3}+0.28 . \mathrm{X}_{4}-0.07 \mathrm{X}_{1}{ }^{2}-$ $1.13 \mathrm{X}_{2}^{2}-6.42 \mathrm{X}_{3}^{2}-6.43 \mathrm{X}_{4}^{2}+3.25 \mathrm{X}_{1} \mathrm{X}_{2}+5.72 \mathrm{X}_{1} \mathrm{X}_{3}+2.31 \mathrm{X}_{1} \mathrm{X}_{4}-5.81 \mathrm{X}_{2} \mathrm{X}_{3}$ $+1.63 \mathrm{X}_{2} \mathrm{X}_{4}+4.62 \mathrm{X}_{3} \mathrm{X}_{4}$

The predicted levels of cell viability, biomass and acidity in fermented vegetable juices using the above equations are given in Table 6, along with experimental data. The usefulness of the present model could be checked with the determination coefficient $\left(\mathrm{R}^{2}\right)$ and correlation coefficient $(\mathrm{R})$. The determination coefficient $\left(\mathrm{R}^{2}\right)$ was calculated as 0.912 for cell viability, 0.918 for biomass and 0.920 for acidity, indicating that the statistical model can explain above $90 \%$ of the variability in the response, showed that models for each response variable were well fitted to explain the relationships among the variables and only about $10 \%$ of the total variation could not be attributed to the independent variables. Normally, a regression model with $\mathrm{R}^{2}$ value more than 0.90 is considered as a high correlation [29].

Here, the value of $\mathrm{R}$ for all three response variables, for cell viability $=0.830$, biomass $=0.837$ and for acidity $=0.846$ were higher than 0.80 , indicated a close agreement between the experimental results and the theoretical values predicted by the model equation. Besides the relationship between the predicted and actual experimental values (Figure $5 \mathrm{a}, \mathrm{b}$ and $\mathrm{c}$ ) that plotted points cluster around the diagonal line, indicating better fitness of the model.

Table 5: Actual and coded values of the variables in Central Composite Design.

\begin{tabular}{|c|c|c|c|c|c|c|c|}
\hline Factor & Name & Low actual & Middle Actual & High actual & Low coded & Middle coded & High coded \\
\hline $\mathrm{X}_{1}$ & $\mathrm{pH}$ & 3.1 & 5.2 & 6.8 & -1 & 0 & 1 \\
\hline $\mathrm{X}_{2}$ & Temperature $\left({ }^{\circ} \mathrm{C}\right)$ & 20 & 37 & 42 & -1 & 0 & 1 \\
\hline $\mathrm{X}_{3}$ & Time (h) & 0 & 24 & 72 & -1 & 0 & 1 \\
\hline$X_{4}$ & Sucrose $(\%)$ & 5 & 9 & 14 & -1 & 0 & 1 \\
\hline Response & Name & Units & $\mathrm{Obs}^{\mathrm{a}}$ & Min. & Max. & Mean & Std.Dev. \\
\hline $\mathrm{Y}_{1}$ & Cell viability & $\mathrm{CFU}$ & 30 & 1.1 & 9.1 & 4.9 & 2.80 \\
\hline $\mathrm{Y}_{2}$ & Biomass & OD & 30 & 0.04 & 0.86 & 0.42 & 0.28 \\
\hline $\mathrm{Y}_{3}$ & Acidity & $\%$ & 30 & 0.27 & 0.49 & 0.37 & 0.07 \\
\hline
\end{tabular}

$\mathrm{Obs}^{\mathrm{a}}=$ Observed runs

Table 6: Central Composite Design expérimental design matrix.

\begin{tabular}{|c|c|c|c|c|c|c|c|}
\hline S. No & $\mathbf{A}$ & $\mathbf{B}$ & $\mathbf{C}$ & D & Cell viability (CFU/mL) & Biomass (O.D at $590 \mathrm{~nm}$ ) & Acidity (\%) \\
\hline 1 & -1 & -1 & -1 & 1 & $1.30(2.18)$ & $0.15(0.21)$ & $0.45(0.43)$ \\
\hline 2 & 0 & 0 & 0 & 0 & $8.70(8.76)$ & $0.82(0.83)$ & $0.29(0.29)$ \\
\hline 3 & -1 & 1 & -1 & 1 & $1.20(2.32)$ & $0.07(0.17)$ & $0.47(0.45)$ \\
\hline 4 & 1 & 1 & -1 & -1 & $1.80(2.45)$ & $0.10(0.16)$ & $0.48(0.46)$ \\
\hline 5 & 0 & 0 & 0 & 0 & $9.10(8.76)$ & $0.86(0.83)$ & $0.27(0.29)$ \\
\hline 6 & 0 & 0 & 0 & -2 & $1.10(0.81)$ & $0.05(0.02)$ & $0.49(0.49)$ \\
\hline 7 & 1 & 1 & 1 & -1 & $4.20(4.62)$ & $0.38(0.44)$ & $0.34(0.34)$ \\
\hline 8 & 1 & 1 & -1 & 1 & $2.00(2.97)$ & $0.10(0.17)$ & $0.48(0.46)$ \\
\hline 9 & 0 & 0 & 0 & 0 & $8.70(8.76)$ & $0.82(0.83)$ & $0.29(0.29)$ \\
\hline 10 & 0 & 0 & 0 & 0 & $8.70(8.76)$ & $0.82(0.83)$ & $0.29(0.29)$ \\
\hline 11 & 1 & -1 & -1 & -1 & $1.70(2.62)$ & $0.08(0.15)$ & $0.47(0.45)$ \\
\hline 12 & 0 & 0 & 0 & 0 & $8.70(8.76)$ & $0.82(0.83)$ & $0.29(0.29)$ \\
\hline 13 & 0 & 0 & -2 & 0 & $6.20(4.07)$ & $0.46(0.26)$ & $0.33(0.38)$ \\
\hline 14 & -1 & 1 & -1 & -1 & $2.60(2.98)$ & $0.19(0.23)$ & $0.42(0.41)$ \\
\hline 15 & -1 & -1 & 1 & 1 & $4.90(5.07)$ & $0.41(0.44)$ & $0.36(0.35)$ \\
\hline 16 & -1 & -1 & -1 & -1 & $2.70(3.17)$ & $0.19(0.24)$ & $0.43(0.42)$ \\
\hline 17 & 0 & -2 & 0 & 0 & $8.20(7.06)$ & $0.79(0.66)$ & $0.31(0.35)$ \\
\hline 18 & 0 & 0 & 0 & 0 & $8.70(8.76)$ & $0.82(0.83)$ & $0.29(0.29)$ \\
\hline 19 & -1 & -1 & 1 & -1 & $5.30(5.64)$ & $0.41(0.45)$ & $0.37(0.37)$ \\
\hline 20 & 1 & -1 & 1 & 1 & $5.20(6.12)$ & $0.49(0.56)$ & $0.32(0.30)$ \\
\hline 21 & -1 & 1 & 1 & -1 & $4.90(4.72)$ & $0.44(0.38)$ & $0.33(0.35)$ \\
\hline 22 & 0 & 2 & 0 & 0 & $7.30(6.31)$ & $0.65(0.58)$ & $0.34(0.36)$ \\
\hline 23 & 2 & 0 & 0 & 0 & $3.40(1.99)$ & $0.28(0.13)$ & $0.39(0.44)$ \\
\hline 24 & 1 & -1 & 1 & -1 & $5.80(5.51)$ & $0.51(0.49)$ & $0.35(0.34)$ \\
\hline 25 & -1 & 1 & 1 & 1 & $4.10(4.49)$ & $0.31(0.35)$ & $0.37(0.36)$ \\
\hline 26 & 0 & 0 & 0 & 0 & $8.70(8.76)$ & $0.82(0.83)$ & $0.29(0.29)$ \\
\hline 27 & 1 & -1 & -1 & 1 & $1.80(2.80)$ & $0.04(0.19)$ & $0.48(0.43)$ \\
\hline 28 & 1 & 1 & 1 & 1 & $5.20(5.56)$ & $0.45(0.48)$ & $0.34(0.32)$ \\
\hline 29 & -2 & 0 & 0 & 0 & $2.20(1.48)$ & $0.15(0.09)$ & $0.45(0.45)$ \\
\hline 30 & 0 & 0 & 0 & 2 & $2.60(0.76)$ & $0.21(0.03)$ & $0.43(0.48)$ \\
\hline
\end{tabular}

Std: Standard run order. 


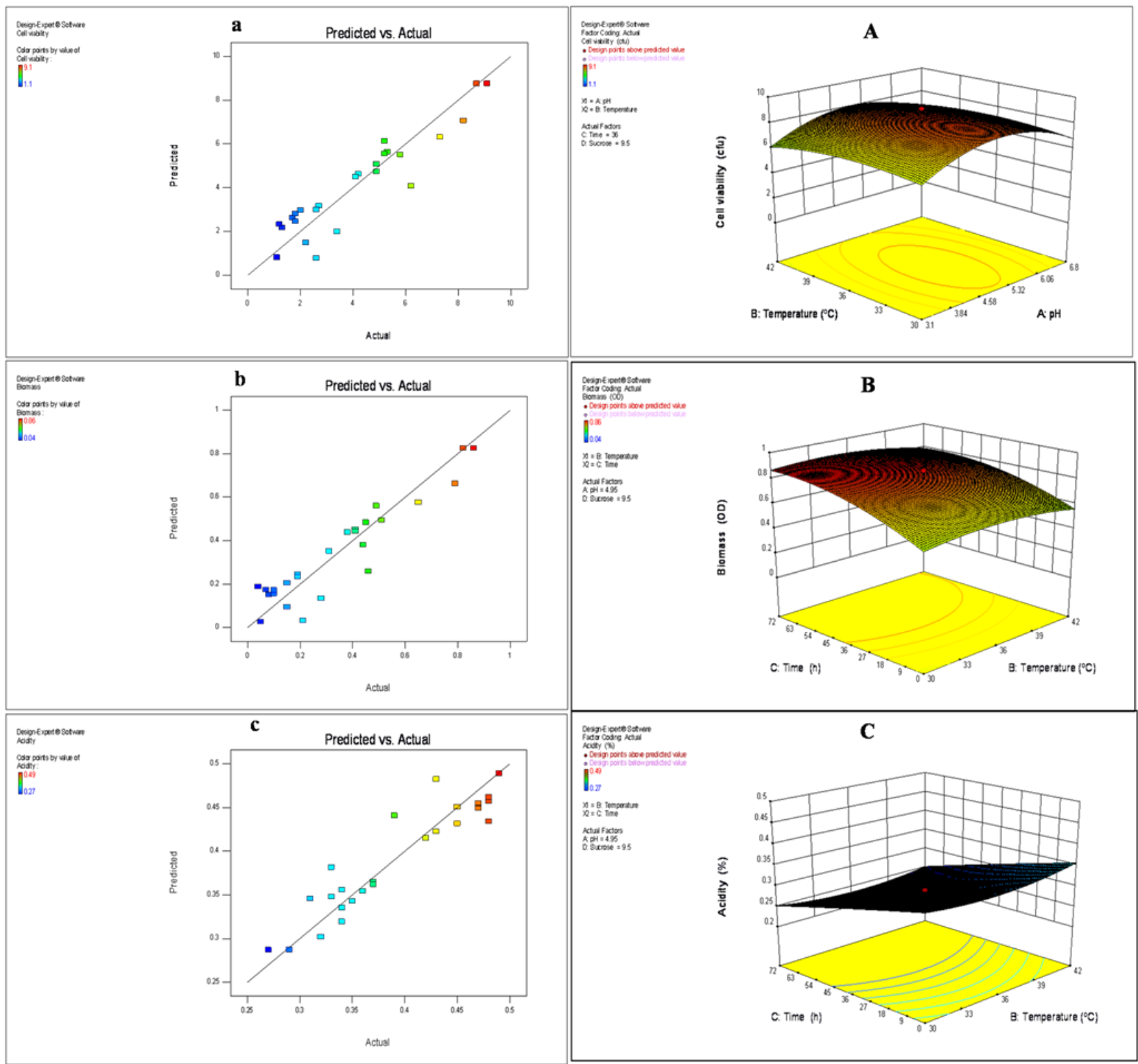

Fig. 5: (a) Predicted and actual levels of $\mathrm{pH}$ and temperature on cell viability; (A) 3D graph represents effect on cell viability; (b) Predicted and actual levels of temperature and time on biomass; (B) 3D graph represents effect on biomass; (c) Predicted and actual levels of pH and time on acidity; (C) 3D graph represents effect on acidity.

From the ANOVA in Table 7, it can be seen that time (58 h) and sucrose (10\%) had strongest influence on cell viability and biomass yield, and $\mathrm{pH}$ showed significant influence on acidity. At higher temperature $\left(42^{\circ} \mathrm{C}\right)$ there was a decrease in the cell viability. Table 7 shows the $F$ test and the corresponding $P$ value along with the parameter estimate. For cell viability, the model terms $X_{1}$ and $X_{2}$ were significant with a probability of $99 \%$. There is a significant interaction in between model terms $X_{1}$ and $X_{2}$ indicates the positive effect of these variables on increase in cell viability in tomato juice. Regarding biomass yield, model terms $\mathrm{X}_{3}$, and $\mathrm{X}_{3}^{2}$ are significant with a probability of $99 \%$ and $\mathrm{X}_{3}$ is significant with a probability of $95 \%$. The significant interaction between the $X_{3}$ and $X_{4}$ process variables will influence on the biomass yield in tomato juice. Considering acidity, the significant probability of $95 \%$ is with the model term $X_{1} .99 \%$ significant probability was shown by the model term $\mathrm{X}_{3}{ }^{2}$ (Table 7). The growth of Lys. sphaericus in the first hour of fermentation resulted in increased biomass, and the adaptation of the microorganism was very fast in both tomato and carrot juices because an increase on cell viability was observed since the beginning of fermentation. There was an increase of $3 \mathrm{log}$ cycle of viable cell counting of Lys. sphaericus during $12 \mathrm{~h}$ of fermentation at $37^{\circ} \mathrm{C}$. At this point, the culture reached the logarithmic growth phase (5.5-7.8 log $\mathrm{CFU} / \mathrm{mL}$ ).

Besides the microbiological safety, the $\mathrm{pH}$ of the medium can influence the viability of probiotic microorganisms. This finding corroborates well with the earlier report of Shah [30], who attributed the decline of $\mathrm{pH}$ and the accumulation of organic acids as the main reasons for viability loss of probiotic microorganisms. 
Table 7: ANOVA of Central Composite Design.

\begin{tabular}{|c|c|c|c|c|c|c|c|}
\hline \multirow[b]{2}{*}{ Source } & \multirow[b]{2}{*}{ Df } & \multicolumn{3}{|c|}{ F-value } & \multicolumn{3}{|c|}{ P-value } \\
\hline & & $Y_{1}$ & $\mathbf{Y}_{2}$ & $\mathbf{Y}_{3}$ & $Y_{1}$ & $\mathbf{Y}_{2}$ & $\mathbf{Y}_{3}$ \\
\hline Model & 14 & 11.13 & 12.42 & 9.86 & $<0.0001$ & $<0.0001$ & $<0.0001$ \\
\hline $\mathrm{X}_{1}$ & 1 & 0.30 & 0.19 & 0.15 & $0.0052 *$ & $0.0111 *$ & $0.0044^{*}$ \\
\hline $\mathrm{X}_{2}$ & 1 & 0.63 & 0.88 & 0.15 & $0.0086^{*}$ & $0.0185^{*}$ & $0.0193 *$ \\
\hline $\mathrm{X}_{3}$ & 1 & 20.48 & 22.63 & 42.27 & $<0.0001$ & $<0.0001$ & $<0.0001$ \\
\hline$X_{4}$ & 1 & 2.800 & 5.221 & 0.066 & $<0.0001$ & $<0.0001$ & $<0.0001$ \\
\hline $\mathrm{X}_{1} \mathrm{X}_{2}$ & 1 & 4.667 & 0.018 & 0.099 & 0.6666 & 0.3062 & 0.1473 \\
\hline $\mathrm{X}_{1} \mathrm{X}_{3}$ & 1 & 0.13 & 1.43 & 3.00 & 0.3384 & 0.2776 & 0.5543 \\
\hline $\mathrm{X}_{1} \mathrm{X}_{4}$ & 1 & 1.03 & 0.44 & 0.89 & 0.3543 & 0.4259 & 0.3868 \\
\hline $\mathrm{X}_{2} \mathrm{X}_{3}$ & 1 & 0.39 & 0.28 & 0.099 & 0.3991 & 0.2197 & 0.6179 \\
\hline$X_{2} X_{4}$ & 1 & 0.079 & 0.031 & 0.62 & 0.3933 & 0.4586 & 0.2827 \\
\hline $\mathrm{X}_{3} \mathrm{X}_{4}$ & 1 & 0.13 & 0.070 & 0.40 & 0.0088 & 0.0085 & 0.1061 \\
\hline $\mathrm{X}_{1}^{2}$ & 1 & 63.91 & 68.79 & 43.30 & 0.0005 & 0.0005 & 0.0061 \\
\hline $\mathrm{X}_{2}{ }^{2}$ & 1 & 5.56 & 5.79 & 6.95 & 0.6236 & 0.341 & 0.41 \\
\hline $\mathrm{X}_{3}^{2}$ & 1 & 3.56 & 7.58 & 0.031 & 0.0001 & 0.0001 & 0.0018 \\
\hline $\mathrm{X}_{4}^{2}$ & 1 & 82.37 & 86.21 & 67.91 & 0.9906 & 0.6476 & 0.4518 \\
\hline Residual & 20.09 & & & & & & \\
\hline Lack of fit & 19.95 & & & & & & \\
\hline Pure error & 0.14 & & & & & & \\
\hline Cor total & 20.09 & & & & & & \\
\hline
\end{tabular}

Y1 - Cell viability, Y2 - Biomass, Y3 - Acidity.

Recent report has shown, however, that Lys. sphaericus possessed the property of bacteriocin production, which can be used as stable and safe food preservative [13]. Hence, the isolated culture was used to ferment tomato and carrot juices which would perhaps impart the same property.

Response surface graphs showed the effect of four fermentation variables on cell viability, biomass and acidity in the tomato juice. The results indicated that the cell viability and biomass response surfaces had a maximum point with acidity at limiting point. Although, response surface models were useful in indicating the direction in which the variables have to be changed in order to maximize the cell viability, biomass and minimize the acidity. The highest level of cell viability was achieved at lower $\mathrm{pH}$ (3.1) and temperature at $32^{\circ} \mathrm{C}$ (Figure 5A) and there is considerable interaction occurred between these two variables. The response surface plot of biomass indicated that maximum yield of biomass in fermented tomato juice was attained at $32^{\circ} \mathrm{C}$ with longer fermentation time (72 h) (Figure 5B). The low acidity in fermented tomato juice response showed and the results were obtained at lower $\mathrm{pH}$ (3.1) for fermentation with higher fermentation time (Figure 5C). Under the fermentation conditions with $\mathrm{pH}(3.1)$, temperature $\left(32^{\circ} \mathrm{C}\right)$, incubation time $(58 \mathrm{~h})$ and sucrose $(10 \%)$ the cell viability, biomass and acidity were $9.1,0.86$ and 0.27 , respectively. Maintenance of the viability of the probiotic culture during storage is a fundamental condition for the beneficial effects after its ingestion. David and Shah [22] reported that the viability of probiotic microorganisms during storage of food products depends on the factors like, the availability of nutrients, growth promoters and inhibitors. In this study the optimal fermentation time was found in log phase in a short time $(12 \mathrm{~h})$. Stopping the fermentation at this point, the microorganisms still have enough nutrients for their maintenance during refrigerated storage. The exposure of the juice to high temperatures was also short, reducing the risk of the deterioration of nutritional compounds such as vitamins. In this study, no evidence of juice contamination was observed after fermentation or after storage period.

\subsection{Sensorial Evaluation}

Sensory evaluation results indicated good sensory scores for fermented tomato and carrot juices (Figure 6). The fermented juices had better acceptance among the consumers than control juices. Only a marginal difference was noticed between the sensory scores of fermented and control juices. The taste, acidity, mouth feel, aroma, flavour, color and overall acceptance were changed in fermented juices. The results are in agreement with the earlier report of sensory evaluation of probioticated mango and sapota juices using $L b$. plantarum [21].

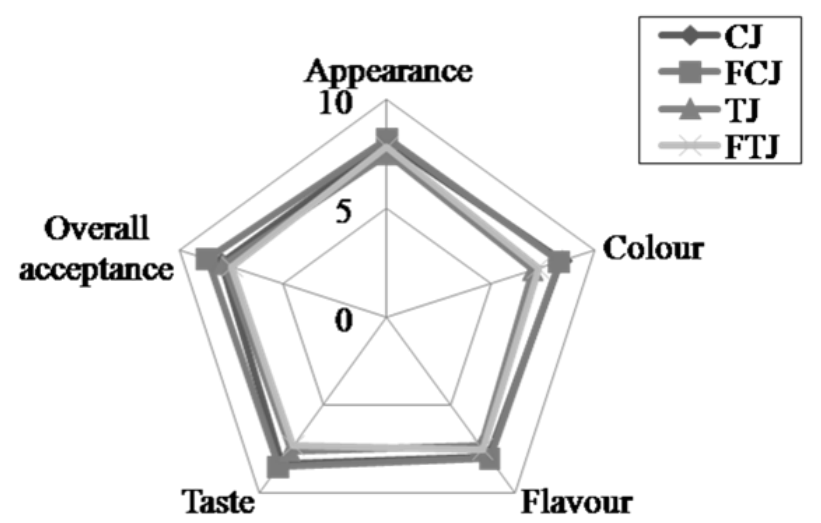

Fig. 6: Sensory evaluation of control and fermented juices CJ (Carrot juice), FCJ (Fermented carrot juice), TJ (Tomato juice), FTJ (Fermented tomato juice

\section{CONCLUSION}

In this study Lys. sphaericus, an isolate from large intestinal tract of fresh water fish, was used for the fermentation of tomato and carrot juices, and the conditions were optimized for 
tomato juice fermentation by using RSM. Good cell viability in both tomato and carrot juices was noticed up to 6 weeks during the cold storage at $4^{\circ} \mathrm{C}$ and no contamination was detected. The fermented juices had a good acceptance in sensory evaluation. Hence, the fermented tomato and carrot juices can be explored as alternatives to dairy based probiotics to get health benefits, especially in lactose intolerance persons.

\section{ACKNOWLEDGEMENT}

We are thankful to Dr. S. C. Basappa, former Deputy Director, Central Food Technological Research Institute (CFTRI), Mysuru, for his encouragement and critical comments on this manuscript.

\section{Financial support and sponsorship: Nil.}

Conflict of Interests: There are no conflicts of interest.

\section{REFERENCES}

1. Menrad K. Market and marketing of functional food in Europe. Journal of Food Engineering. 2003, 53:181-188.

2. FAO/WHO. Report of a Joint FAO/WHO Expert consultation on evaluation of health and nutritional properties of probiotics in food including powder milk with live LAB. Food and Agriculture Organization of the United Nations, World Health Organization. 2001.

3. Yoon KY, Woodams EE, Hang YD. Production of probiotic cabbage juice by lactic acid bacteria. Bioresource Technology. 2006, 97:1427-1430.

4. Sheehan VM, Ross P. Fitzgerald GF. Assessing the acid tolerance and the technological robustness of probiotic cultures for fortification in fruit juices. International Food Science and Emerging Technology. 2007, 8:279-284.

5. Tuorila H, Gardello AV. Consumer response to an off flavour in juice in the presence of specific health claims. Food Quality Preferences. 2002, 13:561-569.

6. Prado FC, Parada JL, Pandey A, Soccol CR. Review: Trends in nondairy probiotic beverages. Food Research International. 2008, 41:111-123.

7. Luckow T, Delahunty C. Which juice is 'healthier'? A consumer study of probiotic non-dairy juice drinks. Food Quality and Preferences. 2004, 15:751-759.

8. Weisburger John H. Can cancer risks be altered by changing nutritional traditions? Cancer. 1998, 83(7):1278-1281.

9. Pandey DK, Shekelle R, Selwyn BJ, Tangney C, Stamler J. Dietary vitamin $\mathrm{C}$ and beta carotene and risk of death in middle-aged men. The Western Electric Study. American Journal of Epidemiology. 1995, 142:1269-1278.

10. Gopalan C, Ramasastry BV, Balasubramanian SC. Nutritive value of Indian foods, National Institute of Nutrition (NIN) Hyderabad. 1996

11. Torriani S, Gardini F, Guerzoni ME, Dellaglio F. Use of response surface methodology to evaluate variables affecting the growth and acidification characteristics of yoghurt cultures. International Dairy Journal. 1996, 6:625-636.

12. Kristo E, Biliaderis CG, Tzanetakis N. Modeling of the acidification process and rheological properties of milk fermented with a yoghurt starter culture using response surface methodology. Food Chemistry. 2003, 83:437-446.

13. Ahmad V, Iqbal AN, Haseeb M, Khan MS. Antimicrobial potential of bacteriocin producing Lysinibacillus jx416856 against food borne bacterial and fungal pathogens, isolated from fruits and vegetable waste. Anaerobe. 2014, 27:87-95.
14. Naga Sivudu S, Harika A, Umamahesh K, Reddy OVS. Isolation, identification and characterization of Lysinibacillus sphaericus from fresh water fish intestinal tract. International Journal of Biology Research. 2017, 2(1):09-13.

15. Mishra V, Prasad DN. Application of in vitro methods for selection of Lactobacillus casei strains as potential probiotics. International Journal of Food Microbiology. 2005, 103:109-115.

16. Box GEP, Behnken DW. Some new three level designs for the study of quantitative variables. Technometrics. 1960, 2:455-475.

17. Vinderola CG, Bailo N, Reinheimer JA. Survival of probiotic microflora in Argentinean yoghurts during refrigerated storage. Food Resource International. 2000, 33:97-102.

18. Casterline Jr, James L, Carolyne J, Oles KU Yuoh. Measurement of sugars and starches in foods by a modification of the AOAC total dietary fiber method. J AOAC Int. 1999, 83:759-765.

19. Singleston VL, Rossi JA Jr. Colorimetric of total phenolics with phospho-molybdic-phosphotungestic acid reagents. American Journal of Enology Viticulture. 1965, 16:144-158.

20. Blois MS. Antioxidant determination by the use of a stable free radical. Nature. 1958, 26:1199-1200.

21. Vijaya Kumar B, Sreedharamurthy M, Reddy OVS. Probiotication of mango and sapota juices using Lactobacillus plantarum NCDC LP20. Nutrafoods. 2015, 14:97-106.

22. David RI, Shah NP. Effect of cysteine on the viability of yogurt and probiotic bacteria in yogurts made with commercial starter cultures. International Dairy Journal. 1997, 7:537-545.

23. Dias DR, Schwan RF, Freire ES, Serodio RD. Elaboration of a fruit wine from cocoa (Theobromaca-cao L) pulp. International Journal of Food Science Technology. 2007, 42:319-329.

24. Suzuki T, Tomita-Yokotani K, Tsubura H, Yoshida S, Kusakabe I, Yamada K, Miki Y, Hasegawa K. Plant growth promoting oligosaccharides produced from tomato to waste. Bioresource Technology. 2002, 81:91-96.

25. Naga Sivudu S, Umamahesh K, Reddy OVS. A comparative study on probiotication of mixed watermelon and tomato juice by using probiotic strains of lactobacilli, International Journal of Current Microbiology and Applied Sciences. 2014, 11:977-984.

26. Yoon KY, Woodams EE, Hang YD. Probiotication of tomato juice by lactic acid bacteria. Journal of Microbiology. 2004, 42; 315-218.

27. Kumar M, Tiwari SK, Srivastava S. Purification and characterization of enterocin LR/6 a new bactericin from Enterococcus faecium LR/6. Applied Biochemistry Biotechnology. 2010, 160:40-49.

28. Sanjay KR, Kumaresan N, Manohar B, Umeshkumar S, Vijaya Lakshmi G. Optimization of carotenoids production by Aspergillus carbonarius in submerged fermentation using RSM. International Journal of Food Engineering. 2007, 3:19-27.

29. Haaland PD. Separating signals from the noise. In Experimental design in biotechnology; Marcel Dekker: New York. 1989.

30. Shah NP. Functional foods, probiotics and prebiotics. Food Technology. 2001, 55:46-53.

\section{How to cite this article:}

Seelam NS, Akula H, Katike U, Obulam VSR. Production, characterization and optimization of fermented tomato and carrot juices by using Lysinibacillus sphaericus isolate. J App Biol Biotech. 2017; 5 (04): 066-075. 